\title{
CHEMICAL AND WOOD ANATOMICAL PROPERTIES OF TUMOROUS WOOD IN A TURKISH WHITE OAK (QUERCUS ROBUR SUBSP. ROBUR)
}

\author{
Sezgin K. Gülsoy ${ }^{1}$, Hüdaverdi Eroğlu ${ }^{1}$ \& Nesime Merev $^{2}$
}

\begin{abstract}
SUMMARY
Chemical and anatomical properties of tumorous and normal wood of Quercus robur L. subsp. robur were compared. Tumorous growth appeared as a result of topping stress. Orientation of cells was severely disrupted in the affected wood. In cross section, aspects of cells changed abruptly from transverse to longitudinal, and in tangential section all wood elements appeared to turn around each other like a fingerprint. Vessel elements and fibres of affected wood were shorter than those of healthy wood. The vessels of affected wood were smaller in diameter especially in the earlywood. On the other hand, multiseriate ray height was shorter than that of normal wood. In addition, perforated ray cells occurred. The ray and axial parenchyma cells of tumorous wood contained dark coloured phenolic compounds. Normal wood had calcium oxalate crystals, while tumorous wood did not. Chemical analyses showed that hemicellulose content and solubility rates in $1 \% \mathrm{NaOH}$, cold water, hot water, and alcohol-benzene were higher than those of normal wood. Cellulose and ash contents of tumorous wood were slightly lower than in normal wood. In addition, air-dry specific gravity of tumorous wood was higher than that of normal wood.
\end{abstract}

Key words: Topping stress, tumorous wood, wood anatomy, chemical structure, White oak.

\section{INTRODUCTION}

Tumorous wood can be developed either by an increase in the rate of formation of new cells or by prolongation of growth period (White 1958a; Peterson 1961; Tsoumis 1965; White et al. 1967; Rickey et al. 1974; Eom 1991). The causes of wood tumour have not been completely identified, but hypotheses suggesting genetic instability, cambial injury by insects and bacteria, sea water spray, or deregulated synthesis of auxin and cytokinin have all been proposed (Eom \& Chung 1994). When the cambium is injured during the growing season or its normal activity is modified, a tree may form various kinds of abnormal tissue such as tumorous wood, burl, etc. (Eom \& Chung 1994). According to Crane et al. (1995), trees with galls or tumours are genetically more resistant to decay, because gall formation is antagonistic to decay by microorganisms.

1) Zonguldak Karaelmas University, Bartin Faculty of Forestry, 74100, Bartin, Turkey.

2) Black Sea Technical University, Faculty of Forestry, 61080, Trabzon, Turkey.

Associate Editor: Susan Anagnost 
In earlier studies, the anatomy of tumorous wood has largely been confined to softwoods (Eom 1991). Some studies were made on Picea glauca (White \& Millington 1954; White 1958a, b; White et al. 1967). Peterson (1961) studied Pinus contorta, Pinus flexilis, Pseudotsuga menziesii, Abies lasiocarpa and Picea engelmannii. Hardwood tumour anatomy was described of Erica arborea (Tsoumis et al. 1988) and Ailanthus altissima (Eom \& Lee 1989). Rickey et al. (1974) studied the chemical structure of tumorous Picea sitchensis. The purpose of this study was to investigate anatomical and chemical properties of tumorous wood of Quercus robur L. subsp. robur, caused by topping stress.

\section{MATERIAL AND METHODS}

A tumorous wood sample was obtained from a 112-year-old living stem of Quercus robur L. subsp. robur growing in Bartin province of Turkey. Tumorous wood of the affected tree was at $280 \mathrm{~cm}$ above ground level. The height and width of tumorous wood samples were $30 \mathrm{~cm}$ and $24 \mathrm{~cm}$, respectively. Affected trees are topped every 5-10 years for use as fuel wood. For comparison, two samples of normal wood were also obtained both from the opposite side of the tumorous wood and from another, healthy tree. The healthy tree was living in the same area and also was 112 years old.

All samples were subdivided into blocks of about $1 \mathrm{~cm}^{3}$ each. Tumorous wood blocks were fixed in formaldehyde. Blocks were softened in $10 \%$ ethylenediamine at room temperature for 3-4 days because of the hardness. Then they were rinsed with distilled water, and dehydrated under vacuum (Kukachka 1978). Transverse, radial, and tangential sections were cut, 15-20 $\mu \mathrm{m}$ thick, and sections were stained with safranin 0 and alcian blue. Sections were mounted on microscope slides with glycerin gelatine to prepare permanent slides.

Small wood pieces the size of matchsticks taken from each sample were macerated in Schultze's solution for a week at room temperature. The samples were then agitated gently to disintegrate individual fibres (Berlyn \& Miksche 1976) and dehydrated with ethyl alcohol and stored in glycerin after staining with safranin.

Tangential diameters of 25 earlywood and latewood pores, and heights and widths of 25 multiseriate rays were measured. Lengths of 50 randomly selected fibres and vessel elements and widths of 25 fibres and fibre lumina were measured in macerations. In addition, 25 counts of vessel element numbers per $\mathrm{mm}^{2}$ were made. Vessel element length including tails were measured at the widest part of the macerated cell (Carlquist 1988). Measurements and counts were made according to the IAWA Committee on Nomenclature (1964).

Tappi T $257 \mathrm{~cm}-02$ standard (2002) was used in preparation of samples for chemical analyses. Lignin content, ash ratio, solubility values in $1 \% \mathrm{NaOH}$, cold water, hot water, and alcohol-benzene were determined according to Tappi standard methods (Tappi 1997, 1999, 2002). Cellulose and holocellulose content were determined according to Kurschner and Hoffer (1929) and Wise's chlorite method (Wise \& John 1952), respectively. Air-dry specific gravity of tumorous and normal wood samples was determined according to the Turkish Standard 2472 test method (1976). 


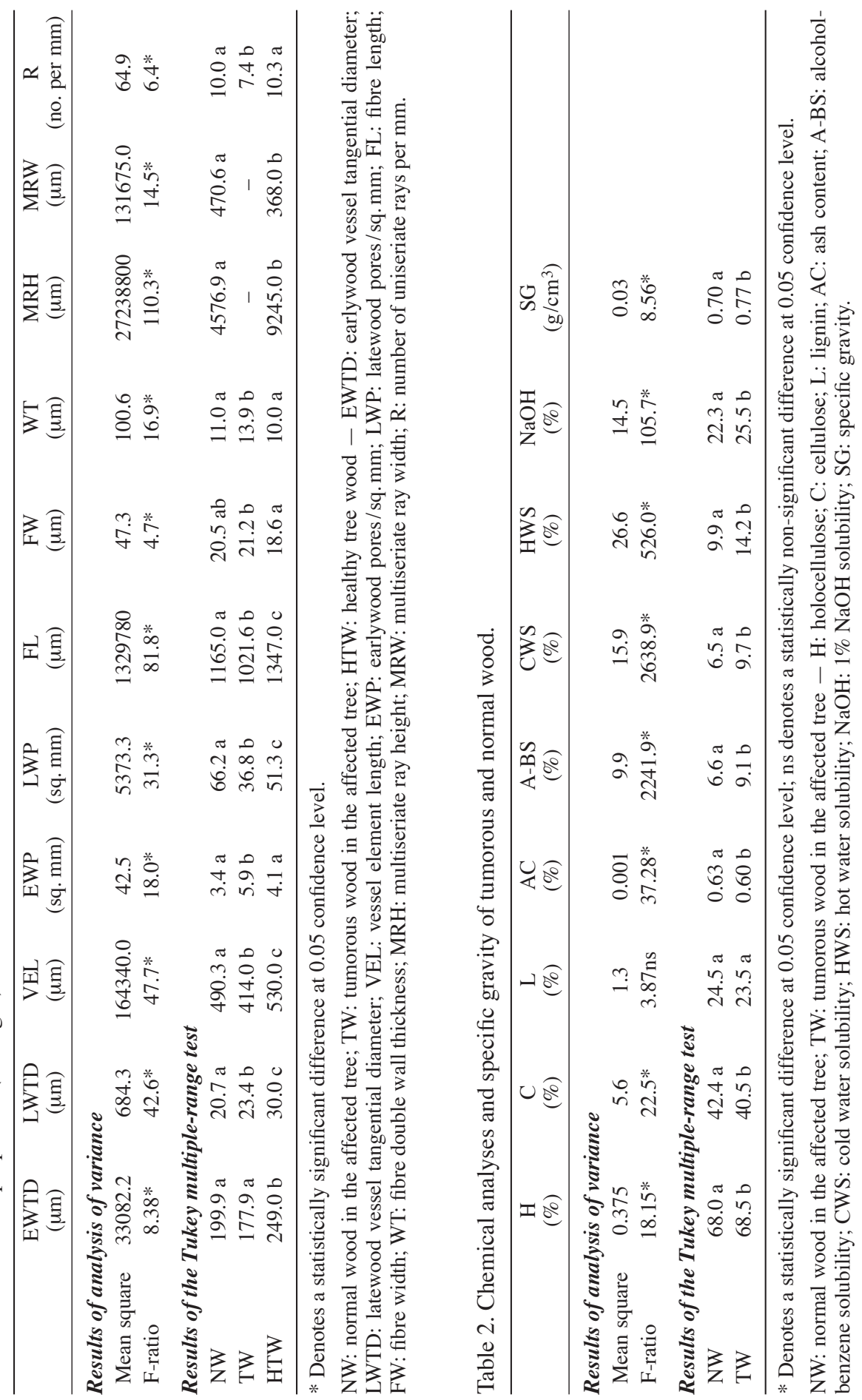




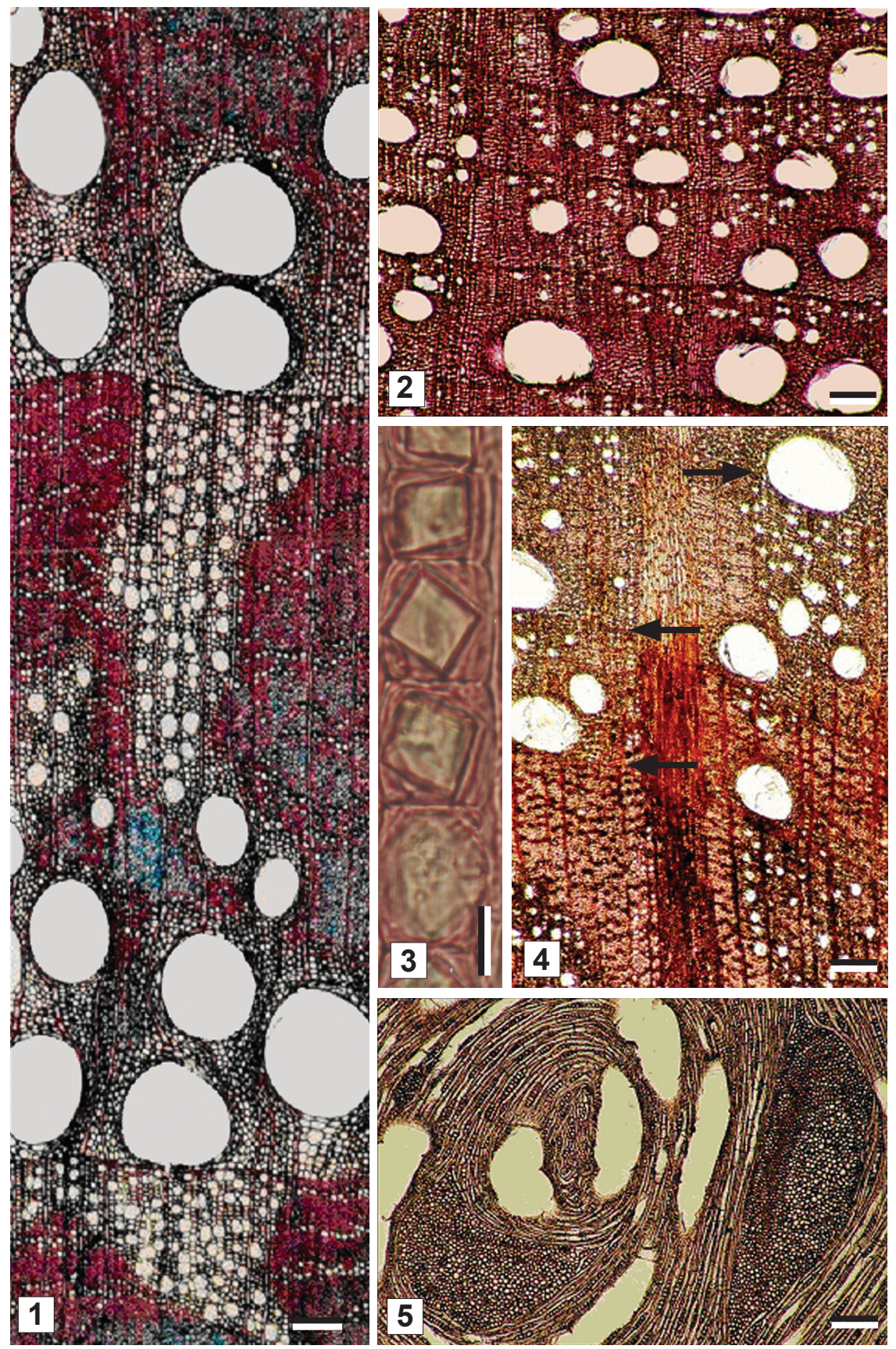

Fig. 1-5. Healthy and affected wood. -1 : Wood ring porous. $-2 \& 4$ : Tumorous wood with phenolic compounds, orange-red or brownish-red, in ray and axial parenchyma cells, irregular growth ring boundary (arrows). - 3: Chambered crystals in axial parenchyma (RS). - 5: Whirled arrangement of axial elements around ray cells in tumorous wood. - Scale bars $=200 \mu \mathrm{m}$ in $1 ; 100 \mu \mathrm{m}$ in $2,4 \& 5 ; 40 \mu \mathrm{m}$ in 3 . 

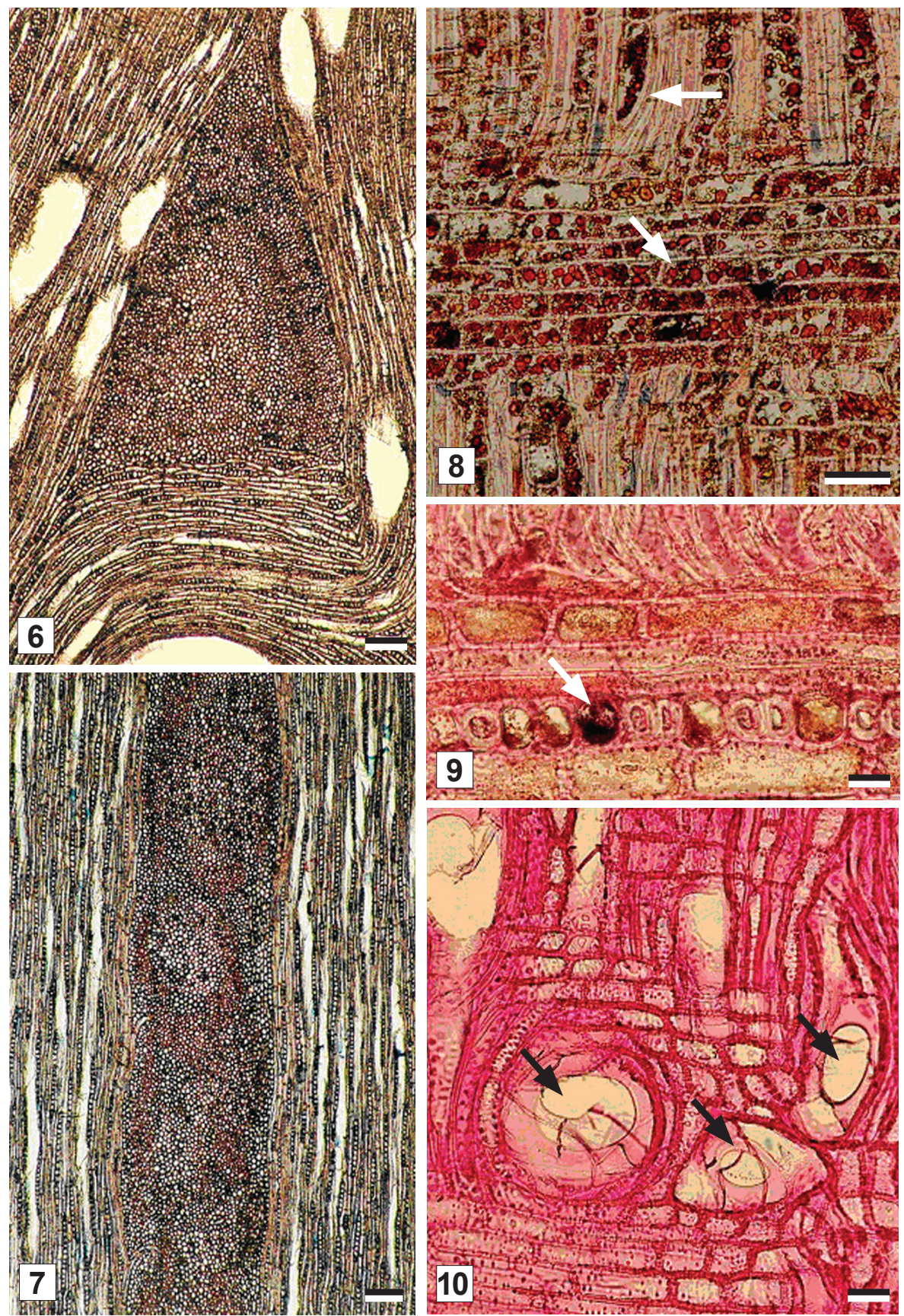

Fig. 6-10. Healthy and affected wood. - 6: TS, triangle-shaped multiseriate ray in tumorous wood. 7: Multiseriate ray of healthy tree. $-8-10$ : RS, phenolic coloured compounds in ray and axial parenchyma cells (arrows in 8 \& 9), fibres with coloured compounds (9) and perforated ray cells in ray tissue (arrows in 10). - Scale bars $=100 \mu \mathrm{m}$ in $6 ; 50 \mu \mathrm{m}$ in $7 ; 40 \mu \mathrm{m}$ in $8 \& 10 ; 10 \mu \mathrm{m}$ in 9 . 


\section{RESULTS AND DISCUSSION}

\section{Wood anatomical description of the healthy tree wood}

Vessels are almost exclusively solitary, forming flame-like or dendritic patterns in latewood; transition from earlywood to latewood vessels is abrupt (Fig. 1). Anatomical properties of normal and tumorous wood of Quercus robur subsp. robur are given in Table 1.

The ground tissue is composed of libriform fibres with simple pits and fibre-tracheids with bordered pits; vasicentric tracheids are abundant and associated with the earlywood vessels. Libriform fibres are 1347 (824-1948) $\mu \mathrm{m}$ long, 18.6 (7.5-28.0) $\mu \mathrm{m}$ wide, and thick-walled $(2.8-8.4 \mu \mathrm{m})$. Likewise, fibre-tracheids are $831(550-1222) \mu \mathrm{m}$ long, 22.5 (13.1-31.7) $\mu \mathrm{m}$ wide, and thin-walled (2.8-6.5 $\mu \mathrm{m})$ with bordered pits in the radial and tangential walls. Axial parenchyma is apotracheal diffuse-in-aggregates and scanty paratracheal in earlywood; parenchyma strands 8- (4-6)-celled. The number of uniseriate rays per mm was 10.3 rays $/ \mathrm{mm}$ (in tangential section). Solitary crystals present (but not abundant) in ray cells and and in chambered axial parenchyma cells (Fig. 3).

\section{Wood anatomical description of the affected wood of the tree}

The typical flame-like arrangement of the latewood vessels in the abnormal side of wood was less pronounced (Fig. $2 \& 4$ ). For quantitative vessel features see Table 1. Fibres are 1165 (738-1521) and 1021 (650-1320) $\mu \mathrm{m}$ long in the normal and abnormal side of wood, respectively. The widths of fibres are 14.3-24.9 and 15.2-27.8 $\mu \mathrm{m}$; and the double wall thickness of fibres is 7.1-14.3 and 10.1-20.2 $\mu \mathrm{m}$ in the normal and abnormal side of wood, respectively. The multiseriate rays of tumorous wood were not measured because of their irregular or triangular shape (Fig. 6). Crystals were not observed. In tangential section of tumorous wood all wood elements appeared to turn around each other like a fingerprint (Fig. 5). Fingerprint formation is absent in normal wood (Fig. 7).

The tangential diameter of earlywood vessels in the tumorous wood was smaller than that of normal wood. Vessel elements and fibres in the tumorous wood were shorter than those of normal wood. Eom (1991) and Crane et al. (1995) indicated similar results in Robiniana pseudoacacia and Populus tremuloides, respectively. At the same time, the orientation of axial elements deviated from the longitudinal axis of the tree. Such deviations were also observed in Pinus densiflora (Eom \& Chung 1994), Ailanthus altissima (Eom \& Lee 1989), and Juglans nigra (Smith 1980). Ray and axial parenchyma cells were filled with dark coloured deposits (Fig. 4, 8, 9). These deposits are most likely phenolic compounds (Crane et al. 1995). Calcium oxalate crystals of common occurrence in opposite and normal tree wood were absent from tumorous wood. However, perforated ray cells (Fig. 10) were only seen in tumorous wood.

The number of latewood vessels per square $\mathrm{mm}$ in the normal wood of the affected tree was higher than that of the healthy tree. The width of multiseriate rays in the normal wood of the affected tree was wider than that of the healthy tree.

Chemical analyses of tumorous and normal wood of Quercus robur subsp. robur are given in Table 2. The holocellulose content of tumorous wood was slightly higher than 
that of normal wood. Cellulose, lignin, and ash contents of tumorous wood were slightly lower than those in normal wood. However, solubility values of tumorous wood were significantly higher than those of normal wood. Rickey et al. (1974) in Picea sitchensis also noted that hemicellulose content in tumorous wood was higher than in normal wood. Crane et al. (1995) noted that in gall wood of Populus tremuloides lignin content was higher than in normal wood. Tsoumis et al. (1988) found that in tumorous wood of Erica arborea ash and extractive contents were higher than in normal wood.

The air-dry specific gravity of normal and tumorous wood was determined as 0.70 $\mathrm{g} / \mathrm{cm}^{3}$ and $0.77 \mathrm{~g} / \mathrm{cm}^{3}$, respectively. This augmentation in specific gravity of tumorous wood could possibly be attributed to phenolic compounds in ray cells. Das (1994), for abnormal wood of Michelia champaca, and Tsoumis et al. (1988), for tumorous wood of Erica arborea, noted that specific gravity of tumorous and abnormal wood was higher than that of normal wood.

Consequently, the chemical and anatomical properties of tumorous wood of Quercus robur subsp. robur changed significantly with regard to normal wood due to topping stress.

\section{ACKNOWLEDGEMENT}

This research was supported by TUBITAK and Research Fund of Zonguldak Karaelmas University (No. 2002-59-03-07).

\section{REFERENCES}

Berlyn, G.P. \& J.P. Miksche. 1976. Botanical microtechnique and cytochemistry. Iowa State Univ. Press, Iowa.

Carlquist, S. 1988. Comparative wood anatomy. Springer-Verlag, Berlin.

Crane, P.E., Y. Hiratsuka \& P.V. Blenis. 1995. Black stem galls on aspen: anatomy and histochemistry. Can. J. Bot. 73: 391-415.

Das, D. K. 1994. Abnormality in seasoning behaviour of champa (Michelia champaca) wood and its probable causes. Bangladesh J. For. Sci. 23: 96-98.

Eom, Y.G. 1991. Histological characteristics of tumorous wood formed in a stem of Robinia pseudoacacia L. by artificial fastening. J. Korean For. Soc. 80: 408-415.

Eom, Y.G. \& Y.J. Chung. 1994. Tumor wood anatomy in Korean red pine (Pinus densiflora). IAWA J. 15: 149-155.

Eom, Y.G. \& P.W. Lee. 1989. Anatomical studies on tumorous tissue formed in a stem of Ailanthus altissima Swingle by artificial banding and its subsequent removing treatment: characters of individual elements. J. Korean For. Soc. 78: 287-301.

IAWA Committee on Nomenclature. 1964. Multilingual glossary of terms used in wood anatomy. Zurich.

Kukachka, B.F. 1978. Sectioning refractory woods for anatomical studies. Microsc. Acta 80: 301-307.

Kurschner, K. \& A. Hoffer. 1929. Technologie und Chemie der Papier- und Zellstoff-Fabrikation 26: $125-139$.

Peterson, R. S. 1961. Conifer tumors in the central Rocky Mountains. Plant Disease Rep. 45: 472-474.

Rickey, R. G., J. K. Hamilton \& H.L. Hergert. 1974. Chemical and physical properties of tumoraffected sitka spruce. Wood and Fiber Sci. 6: 200-210. 
Smith, D.E. 1980. Abnormal wood formation following fall and spring injuries in black walnut.

Wood Sci. 12: 243-251.

Tappi. 1997. Test Method T $204 \mathrm{~cm}-97$ : 'Solvent extractives of wood and pulp'.

Tappi. 1999. Test Method T $207 \mathrm{~cm}-99$ : 'Water solubility of wood and pulp'.

Tappi. 2002. Test Method T 211 om-02: 'Ash in wood, pulp, paper, and paperboard. - Test Method

T 212 om-02: 'One percent sodium hydroxide solubility of wood and pulp. - Test Method

T 222 om-02: 'Acid-insoluble lignin in wood and pulp. - Test Method T $257 \mathrm{~cm}-02$ : 'Sampling and preparing wood for analysis'.

Tsoumis, G. 1965. Structural deformities in an epidemic tumor of white spruce, Picea glauca. Can. J. Bot. 43: 176-181.

Tsoumis, G., N. Kezos., I. Fanariotou., E. Voulgaridis \& C. Passialis. 1988. Characteristics of briarwood. Holzforschung 42: 71-77.

Turkish Standard TS 2472. 1976. Wood - Determination of density for physical and mechanical tests.

White, P.R. 1958a. A tree tumor of unknown origin. Proc. Nat. Acad. Sci. U.S. 44: 339-344.

White, P.R. 1958b. An epiphytotic tumor of white spruce, Picea glauca. In: K.V. Thimann (ed.), The physiology of forest trees: 493-510. Ronald Press, New York.

White, P.R. \& W.F. Millington. 1954. The structure and development of a woody tumor affecting Picea glauca. Amer. J. Bot. 41: 353-361.

White, P.R., G. Tsoumis \& F. Hyland. 1967. Some seasonal aspects of the growth of tumors on the white spruce, Picea glauca. Can. J. Bot. 45: 2229-2232.

Wise, L.E. \& E.C. John. 1952. Wood chemistry, Ed. 2. Vol. 1 \& 2. Reinhold Publ. Co., New York. 